\title{
"Social and economic effects of the war conflict in Ukraine for Europe"
}

\begin{tabular}{|c|c|}
\hline \multirow{3}{*}{ AUTHORS } & Nataliia Stukalo iD http://orcid.org/0000-0003-0517-1653 \\
\hline & Anastasiia Simakhova iD http://orcid.org/0000-0001-7553-4531 \\
\hline & R http://www.researcherid.com/rid/T-4300-2017 \\
\hline ARTICLE INFO & $\begin{array}{l}\text { Nataliia Stukalo and Anastasiia Simakhova (2018). Social and economic effects } \\
\text { of the war conflict in Ukraine for Europe. Geopolitics under Globalization, 2(1), } \\
\text { 11-18. doi:https://doi.org/10.21511/gg.02(1).2018.02 }\end{array}$ \\
\hline DOI & https://doi.org/10.21511/gg.02(1).2018.02 \\
\hline RELEASED ON & Tuesday, 19 June 2018 \\
\hline RECEIVED ON & Tuesday, 03 April 2018 \\
\hline \multirow[t]{2}{*}{ ACCEPTED ON } & Tuesday, 12 June 2018 \\
\hline & \begin{tabular}{|l|}
$(c))$ EY-NC \\
\end{tabular} \\
\hline LICENSE & $\begin{array}{l}\text { This work is licensed under a Creative Commons Attribution-NonCommercial } 4.0 \\
\text { International License }\end{array}$ \\
\hline JOURNAL & "Geopolitics under Globalization" \\
\hline ISSN PRINT & $2543-5493$ \\
\hline ISSN ONLINE & $2543-9820$ \\
\hline PUBLISHER & LLC "Consulting Publishing Company "Business Perspectives" \\
\hline FOUNDER & Sp. z o.o. Kozmenko Science Publishing \\
\hline
\end{tabular}

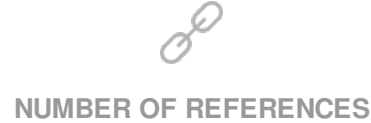

44

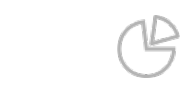

NUMBER OF FIGURES

2

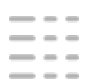

NUMBER OF TABLES

1

(C) The author(s) 2023. This publication is an open access article. 


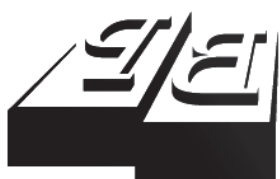

BUSINESS PERSPECTIVES

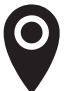

LLC "CPC "Business Perspectives" Hryhorii Skovoroda lane, 10, Sumy, 40022, Ukraine

www.businessperspectives.org

Received on: $3^{\text {rd }}$ of April, 2018 Accepted on: $12^{\text {th }}$ of June, 2018

(C) Stukalo Nataliia, Simakhova Anastasiia, 2018

Nataliia Stukalo, Doctor of Economic Sciences, Professor, Dean of the Faculty of International Economics, Oles Honchar Dnipro National University, Ukraine.

Anastasiia Simakhova, Ph.D. in Economics, Associate Professor, Department of Economics and Management of National Economy, Oles Honchar Dnipro National University, Ukraine.

\section{(ㄷ)(1) $(8)$}

This is an Open Access article, distributed under the terms of the Creative Commons Attribution-NonCommercial 4.0 International license, which permits re-use, distribution, and reproduction, provided the materials aren't used for commercial purposes and the original work is properly cited.
Nataliia Stukalo (Ukraine), Anastasiia Simakhova (Ukraine)

SOCIAL AND ECONOMIC

EFFECTS OF THE WAR

CONFLICT IN UKRAINE FOR EUROPE

\begin{abstract}
The war conflict in the East Ukraine impacts the geopolitical security and stability of Europe and other countries of the world. So, there are the global effects of the war conflict in Ukraine. And the instability in Ukraine has its social consequences that influences the European development. The aim of the article is to identify and elaborate social effects of the war conflict in Ukraine and to get understanding of its influence on European stability, on position of Ukraine on European arena. The article has been prepared by using such methods as: analysis of Ukrainian and European research papers, comparison and generalization of the facts about war conflict in Ukraine. In the article social consequences of the war conflict in Ukraine, such as migration, unemployment, crime growth, decreasing of population and others have been studied. It has been described that social dimension of the war conflict in Ukraine has its influence on European stability and geopolitical situation, especially Ukrainian migration. At the end of the article the authors present the conclusions and the mechanism for solving the war conflict situation in Ukraine. Also, Ukraine needs an integrated approach in order to solve all economic and social problems in the country. Only integrated approach will allow to use available Ukrainian resources and advanced European experience to provide economic and social stability of the country.
\end{abstract}

Keywords

JEL Classification social consequences, geopolitical relations, Ukrainian crisis, war conflict, social problems, Europe

F5, F51, J00

\section{INTRODUCTION}

Much has been written over the past couple of years about social and economic consequences of war and instable situation in Ukraine. One of the main social problems in Ukraine nowadays is conflict situation in the East part of the country that influences all aspects of economic and social life. It is obvious, that the war conflict is not just internal problem of Ukraine, there is an evidence that it influences international and geopolitical relations, international business, international security and sustainability, foreign trade and investments significantly. It is worth to stress some social dimensions of Ukrainian crisis. Actually, there is a lot of them, especially when talking about Ukrainian social and economic situation and development. This study aims to identify and elaborate economic and social effects of war conflict in Ukraine and to get understanding of its influence on European security, on position of Ukraine on European arena. This article is prepared by using the following methods: analysis of scientific Ukrainian and European literature, comparison and generalization of the facts about war conflict in Ukraine.

Structurally the article is composed by investigation of theoretical background of this problem by research of social effects of instability in Ukraine through the prism of migration processes, welfare of population, unemployment and crime situation and proposition of the solution social dimension of war conflict in Ukraine in the European aspect. 


\section{LITERATURE REVIEW}

Different aspects of the war conflict problematic have been studied by many scholars. In general, the theory of conflicts was investigated by Carroll (1970), Lake (2003), Sharma (2015), who described the types, ways, tools and other aspects of conflicts in world community. The geopolitical aspects of war conflicts was studied by Woon (2014).

The influence of the war conflicts on European security is the main theme of works of such scholars as Averre (2016), Stewart et al. (2006), Hopmann (2003). Some of them pay attention to war conflict in Ukraine.

The meaning of the Ukrainian war conflict for the West has been investigated by Wilson (2014). Negative aspects of crisis on Ukrainian society's life have been discussed by such scientists as Jonsson and Seely (2015), Wisehart (2014).

The Russian intervention in Ukraine (annexation of Crimea, the beginning of the war conflict in the Eastern Ukraine) and its reasons have been described in the article of Allison (2014). The author wrote about such reason of war conflict in Ukraine as geopolitical and geoeconomic competition between EU/NATO and Russia for Ukrainian way of development. The works of the authors Sutyagin (2015) and Dugas (2016) have told about conflict situation in Ukraine, as the all international rules violation by Russia, such as violation of Ukrainian sovereign territory.

Kurowska (2014) and Shelest (2015) have studied different aspects of Russian annexation of Crimea as a part of Russian multipolarity politics and the start of war conflict. The sources of RussianUkraine war conflict has been investigated by Kiryukhin (2016). The scientist considers that the conflict between countries began after the development of conservative tendencies in the both countries.

Geopolitical aspect and challenge of the Ukrainian crisis for Europe have been studied by AlexandrovaArbatova (2016), Rojansky (2014). The first author told that situation in Ukraine is the first direct conflict between different regional strategies of Russia and the EU.
Some scholars have investigated instability in Ukraine as the result of the crisis relations between Russia and European Union (Haukkala, 2015; Smith, 2015). These authors have found some deep reasons of the Ukrainian unstable situation as conflicts between EU and Russia. The author Dergachev (2001) and Davis (2016) have written about the influence of UkrainianRussian relations on European countries before and after the beginning of war conflict in Ukraine. It is also our point of view to investigate effects of the war conflict in Ukrainian through the prism of the relations between whole Europe and Russia.

Despite the research of mentioned above authors, the issue of a comprehensive assessment of the social impact of the Ukrainian crisis on the European arena remains open. This article is designed to investigate this problematic issue. Europe is a geographic neighbor of Ukraine and Russia, who has a military confrontation.

Moreover, the globalization and world's transformation into a single interrelated mechanism lead to the fact that the activities of each country can be harmful not only to their neighbors, but to the whole world, as in the case of Ukrainian war conflict. So, it is necessary to assess the consequences of the crisis in Ukraine not only for regional, but also for European and even world security.

The article starts from the most obvious point - economic and social dimensions framing current European-Russia-Ukraine relationships.

\section{METHODS}

In the article the following scientific methods are used: systematization, comparison, generalization, analysis and synthesis. These methods were used to investigate the current situation in economic and social sphere in Ukraine and its effects for European countries.

The information base of the research consists of articles of Ukrainian and foreign scientists, materials of international institutions and own scientific developments. 
The article includes the analysis of theoretical framework as well as empirical data of economic and social consequences of war conflict in Ukraine.

\section{RESULTS}

The role of social sphere in the human living conditions, and enhancement of capabilities to fulfill human potentials increasing in national economy (Sardak et al., 2017, p. 6). It is natural that an effective social sphere can't exist without a strong economic base (Simakhova, 2016, p. 263). The economy of Ukraine is in crisis, the Eastern regions of the country are involved in war conflict. So, all these facts are negatively reflected in Ukrainian social and economic sphere.

Major social challenges are: social security, problem of employment, financial support of Ukrainians, psychological adaptation.

The military actions in Eastern Ukraine led to some social problems that influence the social development of Europe. The main problem is Ukrainian migration. Driven by war conflict people are migrating to other countries looking for a better quality of life (Firoz \& More, 2016). So, since 2014 a number of Ukrainians have requested asylum in European countries. In December 2015 there were 1,345 asylum applicants from Ukraine in Europe, in December 2016 their number was 700 (Eurostat, 2016). Nevertheless, such amount of Ukrainians brings the problem of their social support and well-being to the European countries. As for specific areas of migration, the Ukrainian have chosen Portugal, Czech Republic, Poland, Malta, Liechtenstein, Spain. So, the Ukrainians have applied asylum mainly in the South and Eastern European countries. The main reason of this fact is the similar social and economic model of these countries with Ukrainian social economy model (Stukalo \& Simakhova, 2018).

There is critical situation in Europe with migrants. Last several years their number has been increased. According to European statistics, in 2015 , the EU countries with the largest inflows of foreign nationals were Germany $(1.46 \mathrm{mln})$, the
UK (0.548 ml.), Spain (0.29 mln) and Italy (0.25 mln) (Hawkins, 2017, p. 19).The number of people acquiring the citizenship of an EU Member State in 2015 was 841.2 thousand, among them 292.54 thousand migrants from 5 countries - Syria, Eritrea, Iraq, Afghanistan, Iran (Eurostat, 2017). Thus, war conflict in Ukraine creates another critical migration zone in Europe. As in European countries also there are problem of youth migration (Menshikov et al., 2017).

The problem of migration of the Ukrainian population to Europe is exacerbated by the fact that in Ukraine the average annual wages are almost 10 times lower than in European countries (Figure 1). Thus, the crisis situation in Ukraine has created a zone of social instability in Europe. Today, cause of the war conflict in Ukraine, there is no possibility for high economic development and raising the standard of living for the Ukrainian population. Therefore, the solution of the social and economic consequences of war conflict is a priority not only for Ukraine, but also for Europe.

Another social problem is the appearance of category of internal displaced persons in Ukraine. It is difficult to establish their real amount. However, the official statistics do not reflect the real extent of relocation because some citizens have left the war zone by themselves (moving to relatives, friends, etc. without going through registration).

One more huge problem of the Ukrainian ATO (Anti-terrorist operation) area, it is the psychological adaptation of people from ATO region. Ukrainian psychologists together with representatives of government agencies, local government, public (volunteer) organizations and volunteers have carried a lot of psychological support and assistance to citizens who move from temporarily occupied areas and areas of ATO. But it is very difficult to integrate such people to society again, to find them new job or to return to the previous work place.

Instability in Ukraine led to a general decline of the Ukrainian population (Table 1). Thus, since 2014 the number of people has decreased by 500 thousand people. Mainly, it is due to migration and death of people in the ATO area. 


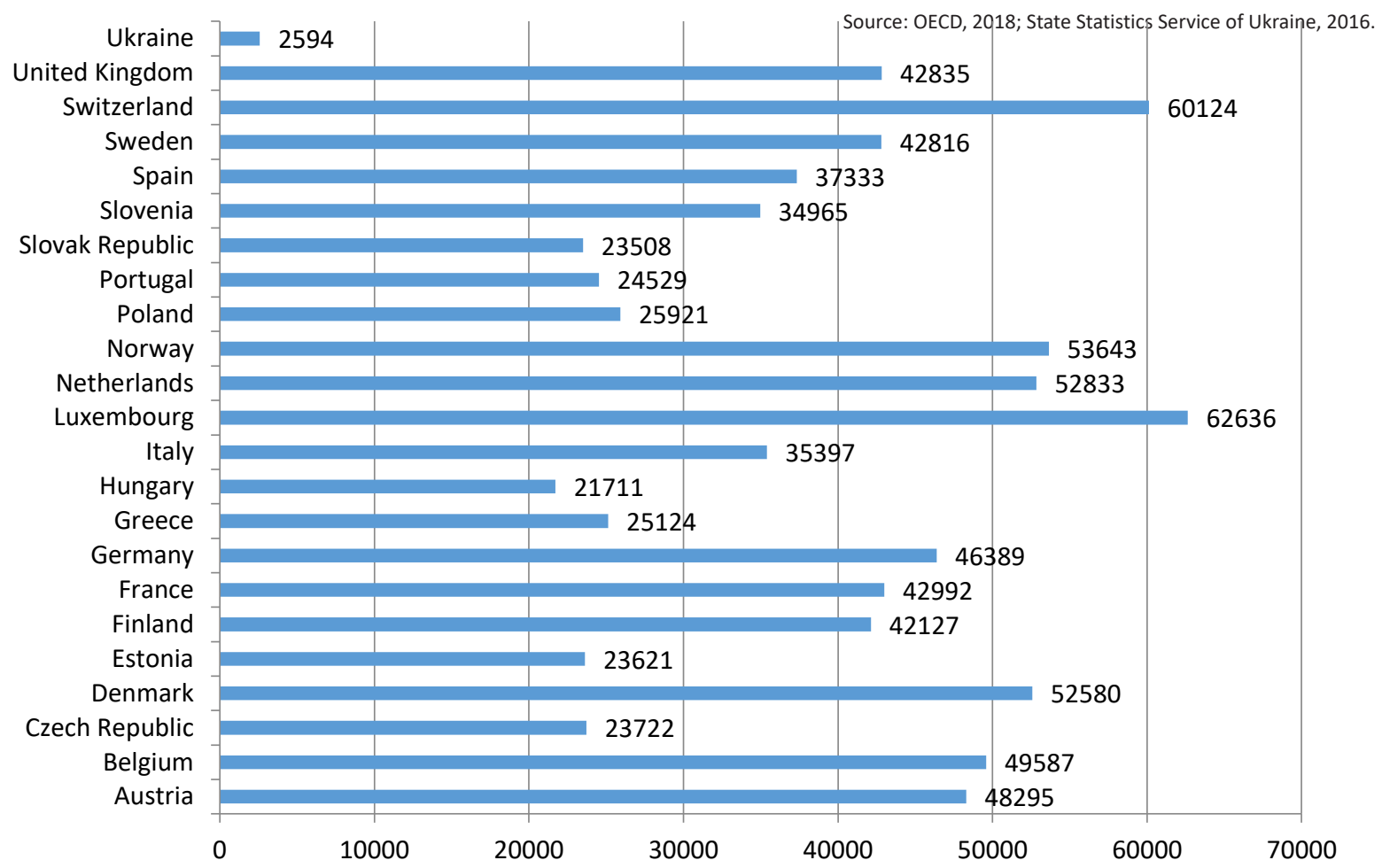

Figure 1. Average annual wages in European countries of OECD and Ukraine in 2016, USD

According to the information in Table 1, the international emigration in Ukraine was very high in 2014, at the beginning of Ukrainian crisis. In 2015, the level of emigration remained high. Officially in 2014-2015 more than 22 thousand people left Ukraine every year. But this is only official data. Obviously, the number of illegal migration is much higher. In 2016, migration has declined and decreased by one third compared to 2015 .

Over the last three years consumer price index has had the highest level in 2015 - 43.3\% (see Table 2). This trend increased poverty in the country, decreased purchasing power of the Ukrainians and caused other social problems.

During 2014-2016 the number of unemployed in Ukraine is higher than $9 \%$. It is also shows the war conflict in Ukraine and its social sphere.

Another negative manifestation of the Ukrainian crisis is the growth of crime. In 2014, about 530 thousand crimes were committed. It is a very high figure. Moreover, it has grown over the next two years by 62 thousand crimes. And in 2016, 592.6 thousand crimes were committed. In 2017 there have been 523.9 thousand crimes. This situation requires an immediate solution. Such a big number of committed crimes also characterize Ukraine as an unstable social zone for Europe.

Thus, the main social challenges of war conflict in Ukraine are people's death, migration, crimes, unemployment, low level of average wages compared with Europe, negative impact on civil socie-

Table 1. Dynamics of social indicators in Ukraine in 2014-2017

\begin{tabular}{|c|c|c|c|c|}
\hline Indicator & 2014 & 2015 & 2016 & 2017 \\
\hline Population, mln. & 42.9 & 42.8 & 42.6 & 42.4 \\
\hline International emigration from Ukraine, persons & 21,599 & 21,409 & 6,465 & No data \\
\hline Consumers price index changes, $\%$ & 24.9 & 43.3 & 12.4 & 13.7 \\
\hline Unemployment, \% & 9.7 & 9.5 & 9.7 & 9.9 \\
\hline Number of crimes, thousand & 529.1 & 565.1 & 592.6 & 523.9 \\
\hline
\end{tabular}


Source: Developed by authors.

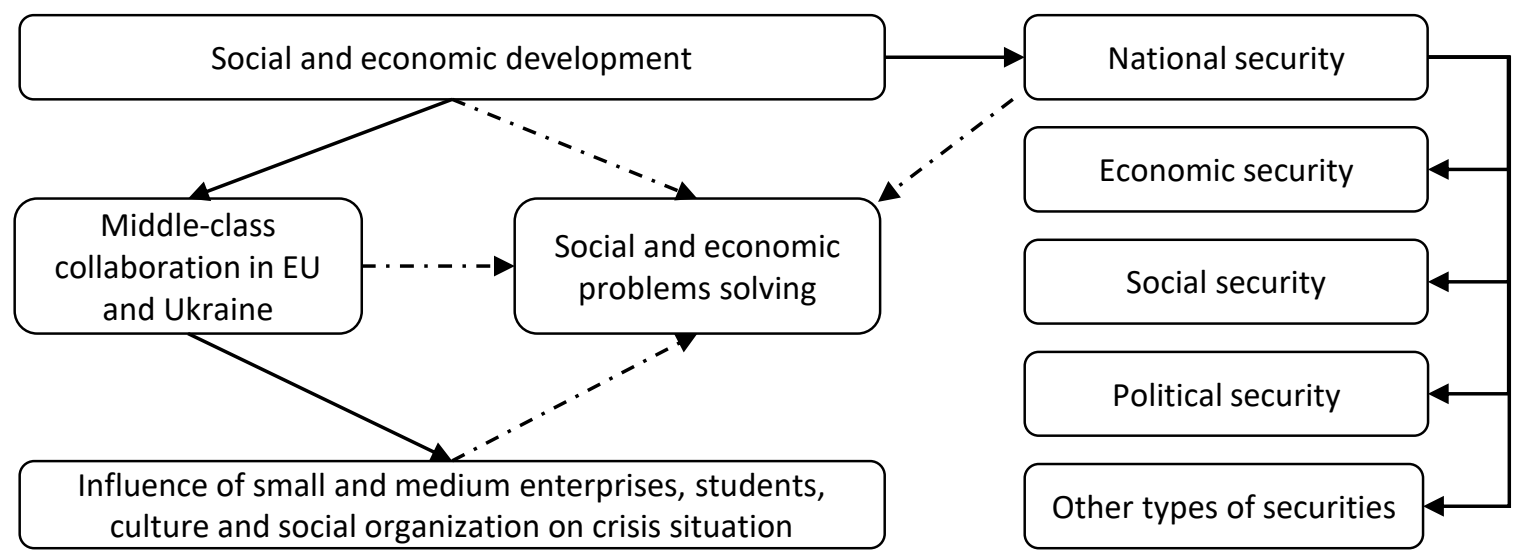

Figure 2. Mechanism of social and economic problems of war conflict in Ukraine solving (European aspect)

ty and socialization, necessity of infrastructure rebuilding. All these social effects of war conflict in Ukraine have formed unstable zone in Europe and have influenced geopolitical relations in Europe.

Undoubtedly, Ukraine needs a special approach to solve all social and economic problems in the country. Only integrated approach will make it possible to use available Ukrainian resources and advanced European experience. Thus, the mechanism to solve social and economic problems of Ukrainian crisis were proposed (Figure 2).

One of the main problems are social challenges that have a number of different problematic components. It is past and present situation.

Based on this, the proposed areas of problem solving are such as middle-class collaboration in EU and Ukraine, non-political tools (influence of small and medium enterprises, students, culture, social organization and environment on Ukrainian situation).

One of the important tasks for the future Ukrainian development is to ensure security, which undoubtedly will have positive effect on economic and social sphere. The concept of "security" fulfills a methodological function, because it acts as a conceptual idea for explaining certain specific processes and phenomena of social reality. Moreover, economic security is determined by the set of social benefits that are necessary for a decent life of society. Thus, safety is important for the stability of Ukraine's social life.
Security activities have a horizontal and vertical dimension. The horizontal effect refers to ensuring the security of the individual, enterprise, region, state, society, international community that is significant for Ukraine today. The vertical dimension of security is political, military, economic, information, social, scientific and technological and other types of securities. It is worth to mention, that it is important for Ukraine to ensure security in both vertical and horizontal effects and at all levels. Only in this way it will be possible to solve effectively the social consequences of the Ukrainian crisis.

Considering the problems of security providing, the question arises of borders of national sovereignty and opportunities of international organizations or other global actors to interfere. In the case of Ukraine, the weak activity of international institutions can be indicated that makes it impossible to stop bloody confrontation. So, the EU and the USA should be active in resolving the Ukrainian-Russian conflict. These two global actors can and should play the central role in the peace negotiations between Ukraine and Russia, as well as in strategic efforts aimed in creating conditions for the final solution.

In the post-conflict reconstruction period it is the important task to achieve the social stability and well-being in Ukraine. The allocation of profits between state and producing regions is also a significant issue (Lujala et al., 2010). It can facilitate to reach productive results in Ukrainian social and economic development and security. Effective social and economic efforts should direct to provide 
conditions for increasing of international trade, foreign direct investments in national economy and also investments into human capital.

Thus, in the post-crisis period, the social economy will have a positive effect on the social and economic growth of Ukraine. Social economy facilitates the acceleration of the process of material and non-material goods production, and also, in some way, restricts access to traditionally accessible social benefits. First of all, such benefits are education and health. The development of the social economy affects, on the one hand, their commercialization, and on the other hand, the increase of consumers. It is important that the injured East-Ukrainian citizens from the Russian-Ukrainian conflict have qualitative and accessible medical care, as well as preferential conditions in the sphere of education.

\section{CONCLUSION}

Ukraine made its choice in favor of European integration, shows solidarity with European values and principles, and confirms its willingness to move towards European integration and to become a part of western civilization. However, for Russia it's hard to accept such a choice and, what is even more important, the Europe and Ukraine will remain living next to unexpected, but still very important neighbor - Russia. It's obvious, Ukraine and other countries of the world need to build new policy towards Russia.

The research shows that Ukrainian crisis brings a lot of social challenges, as people's death, migration, crimes growth, unemployment growth, negative impact on civil society and socialization.

It is necessary to develop constructive and pragmatic approach to ensure peace and stability in Europe and in the whole world. To our opinion such a policy should be based on the key economic pillars which, from the one side, will push parties for dialogue and ensure stopping the war in Eastern Ukraine, and, from the other side, will create new bridges and durable basis for cooperation and stability in Europe and the World. Thus, from one side, such a policy should be based on reducing dependency on Russian natural resources, from the other side, it should ensure developing of non-political forms of cooperation beneficial for all sides. So, alternative pillars and bridges are: intellectual elites and middle-class cooperation and relationship development, that play an important role; scientific and educational cooperation (universities, professors); students mobility; cultural and environmental cooperation; small and medium enterprises cooperation.

\section{REFERENCES}

1. Alexandrova-Arbarova, N. (2016). Geopolitical challenges for the post-bipolar Europe. Eastern Journal of European studies, 7(2), 31-46.

2. Allison, R. (2014). Russian 'deniable' intervention in Ukraine: how and why Russia broke the rules. International Affairs, 90(6), 1255-1297. http://dx.doi. org/10.1111/1468-2346.12170

3. Averre, D. (2016). The Ukrainian conflict: Russia’s Challenge to European security governance. Europe-Asia Studies, 68(4), 699725. https://doi.org/10.1080/09668 136.2016.1176993

4. Ballentine, K. (Ed.) (2003). The Political Economy of Armed Conflict,
Beyond Greed \& Grievance. Colorado: Lynne Rienner Publishers.

5. Carroll, B. A. (1970). War Termination and Conflict Theory: Value Premises, Theories, and Policies. The Annals of the American Academy of Political and Social Science, 392, 14-29.

6. Collier, P. (2007). Economic Causes of Civil Conflict and Their Implications for Policy. In Leashing the Dogs of War: Conflict Management in a Divided World. Crocker, Hampson, \& Aall (Eds.). Washington: Institute of Peace Press.

7. Davis, C. M. (2016). The Ukraine conflict, economic-military power balances and economic sanctions.
Post-Communist Economies, 28(2), 167-198. https://doi.org/10.1080/1 4631377.2016.1139301

8. Dergachev, A. (2001). UkrainianRussian relations - European and Eurasian contexts. Russian Politics \& Law, 39(6), 57-63.

9. Dugas, M. E. (2016). Between Georgia and Crimea: the Social Dimensions of War for the Russian Military. (Honors Thesis Collection, No. 336). Retrieved from http://repository.wellesley.edu/ thesiscollection/336

10. Early, B. R., \& Jadoon, A. (2016). Do sanctions always stigmatize? The effects of economic sanctions on foreign aid. Empirical and 
Theoretical Research in International Relations, 42(2), 217-243. https://doi.org/10.1080/03050629. 2016.1093477

11. Eurostat (2016). First time asylum applicants in the EU. Retrieved from http://ec.europa.eu/eurostat/ statistics-explained/index.php/ File:First_time_asylum_applicants_in_the_EU-28_by_citizenship,_Q4_2015_\%E2\%80\%93_ Q4_2016.png

12. Eurostat (2017). International trade in goods. Retrieved from http://ec.europa.eu/eurostat/data/ database

13. Eurostat (2017). Migration and migrant population statistics. Retrieved from http://ec.europa. eu/eurostat/statistics-explained/ index.php/Migration_and_migrant_population_statistics

14. Finch, R. (2015). The Kremlin's Economic Checkmate Maneuver. Problems of Post-Communism, 62(3), 187-191. Retrieved from http://www.tandfonline.com/doi/ abs/10.1080/10758216.2015.102 2392

15. Firoz, M., \& More, B. (2016). Social Inclusion of the Migrant Population in Dubai: A New Paradigm in Housing. The International Journal of Sustainability in Economic, Social, and Cultural Context, 12(4), 19-33. https://doi. org/10.18848/2325-1115/CGP/ v12i04/19-33

16. Haukkala, H. (2015). From cooperative to contested Europe? The conflict in Ukraine as a culmination of a long-term crisis in EU-Russia relations. Journal of Contemporary European Studies, 23(1), 25-40.

17. Hawkins, O. (2017). Migration statistics (Commons Briefing papers SN06077). London: The House of Commons Library.

18. Hopmann, P. T. (2003). Managing Conflict in Post-Cold War Eurasia: The Role of the OSCE in Europe's Security 'Architecture'. International politics, 40(1), 75-100. Retrieved from https://link.springer.com/article/10.1057/palgrave.ip.8800009

19. Jonsson, O., \& Seely, R. (2015). Russian full-spectrum conflict:
An appraisal after Ukraine. The Journal of Slavic Military Studies, 28(1), 1-22.

20. Kiryukhin, D. (2016). Russia and Ukraine: the clash of conservative projects. European Politics and Society, 17(4), 438-452. https://doi.or g/10.1080/23745118.2016.1154130

21. Kurowska, X. (2014). Multipolarity as resistance to liberal norms: Russia's position on responsibility to protect. Conflict, Security \& Development, 14(4), 498-508. https://doi.org/10.1080/14678802.2 014.930589

22. Lake, D. A. (2003). International relations theory and internal conflict: insights from the interstices. International Studies Review, 5(4), 81-89. https://doi.org/10.1111/ j.1079-1760.2003.00504008.x

23. Leal-Arcas, R., Rios, J. A., \& Grasso, C. (2015). The European Union and its energy security challenges: engagement through and with networks, Contemporary Politics, 21(3), 273-293. https://doi.org/10.1 080/13569775.2015.1061242

24. Lujala, P., Rustad, S. A. \& Le Billon, P. (2010). Valuable Natural Resources in Conflict Affected States. In Berdal, M. \& Wennmann, A. (Eds), Ending Wars, Consolidating Peace: Economic Perspectives. Routledge, New York, 121-136.

25. OECD (2018). Average annual wages. http://dx.doi.org/10.1787/ data-00571-en

26. Prontera, A. (2017). Forms of state and European energy security: diplomacy and pipelines in Southeastern Europe. European Security, 26(2), 273-298. https://doi.org/10.1 080/09662839.2017.1313233

27. Radanović, M., Filipović, S., \& Pavlović, D. (2017). Energy prices and energy security in the European Union: Panel data analysis. Energy Sources, Part B: Economics, Planning, and Policy, 12(5), 415419. https://doi.org/10.1080/15567 249.2016.1157649

28. Rojansky, M. (2014). The Geopolitics of European Security and Cooperation. Security and Human Rights, 25, 169-179. https://doi. org/10.1163/18750230-02502006
29. Sardak, S., Bilska, O., \& Simakhova, A. (2017). Potential of economy socialization in the context of globalization. Economic Annals-XXI, 164(3-4), 4-8. https:// doi.org/10.21003/ea.V164-01

30. Sharma, V. S. (2015). A social theory of war: Clausewitz and war reconsidered' Cambridge Review of International Affairs, 28(3), 327347. https://doi.org/10.1080/09557 571.2013 .872600

31. Shelest, H. (2015). After the Ukrainian crisis: is there place for Russia? Southeast European and Black Sea Studies, 15(2), 191-201. https://doi.org/10.1080/14683857. 2015.1060019

32. Simahova, A. O. (2016). Analysis of the foreign economic factors impact on the welfare of Ukrainians in the conditions of the world integration processes. Marketing and Management of Innovations, 3 , 263-271.

33. Simon, M.V. (1995). When sanctions can work: economic sanctions and the theory of moves. Empirical and Theoretical Research in International Relations, 21(3), 203-228. https://doi. org/10.1080/03050629508434866

34. Smith, A. (1995). The success and use of economic sanctions. Empirical and Theoretical Research in International Relations, 21(3), 229-245. https://doi. org/10.1080/03050629508434867

35. Smith, N. R. (2015). The EU and Russia's conflicting regime preferences in Ukraine: assessing regime promotion strategies in the scope of the Ukraine crisis. European Security, 24(4), 525-540.

36. State Statistics Service of Ukraine (2017). Social and Economic Development of Ukraine in 2017. Retrieved from http://www. ukrstat.gov.ua/[Accessed 1 September 2017]

37. State Statistics Service of Ukraine, (2016). Social and Economic Development of Ukraine in 2016. Retrieved from http://www. ukrstat.gov.ua/[Accessed 2 September 2017]

38. Stewart, E. J. (2006). The European Union and conflict Prevention: 
Policy Evolution and Outcome. Berlin: LIT Verlag.

39. Boda, G., Stukalo, N., Stolyarchuk, Y., \& Fejes, J. (2013). Intellectual Capital Paradox: The case of Hungary and Ukraine. Developing Countries Studies, 3(8), 64-81. Retrieved from http://www.iiste.org/ Journals/index.php/DCS/article/ view/7062/7212

40. Stukalo, N., \& Simakhova, A. (2018). Global parameters of social economy clustering. Prob- lems and Perspectives in Management, 16(1), 36-47. https://doi. org/10.21511/ppm.16(1).2018.04

41. Sutyagin, I. (2015). Russian forces in Ukraine. RUSI Briefing Paper. Retrieved from https://rusi.org/ publication/briefing-papers/ russian-forces-ukraine

42. Wilson, A. (2014). Ukraine crisis: what it means for the West. London: Yale University Press.

43. Wisehart, D. (2014). The Crisis in Ukraine and the Prohibi- tion of the Use of Force: A Legal Basis for Russia's Intervention? European Journal of International Law. Retrieved from https://www. ejiltalk.org/the-crisis-in-ukraineand-the-prohibition-of-the-useof-force-a-legal-basis-for-russiasintervention/

44. Woon, C. Y. (2014). Popular Geopolitics, Audiences and Identities: Reading the 'War on Terror' in the Philippines. Geopolitics, 19, 656683. https://doi.org/10.1080/14650 045.2014 .907277 